\title{
ANNOUNCEMENT CONCERNING THE XXIV ASTIN COLLOQUIUM
}

Cambridge, England - 25-29 July 1993

The above Colloquium will take place at historic St John's College, Cambridge, where meetings will be held and where accommodation has been arranged in college. There are also some hotel rooms available.

For further details please see:

International Actuarial Association Bulletin N ${ }^{\circ} 15$ IV-1992,

or contact David GoldER, Conference Officer, Institute of Actuaries, Staple Inn Hall, High Holborn, London WC1V 7QJ, England. 